\title{
Teaching Gender Research Methods for Leadership: Reflections from Rwanda
}

\author{
Jaya Dantas
}

\begin{abstract}
This chapter discusses teaching and research undertaken by the author in Rwanda between 1997 and 2011. The author draws on her experiences of establishing and running an institution in Rwanda from 1997 to 1999, undertaking research for her PhD in 2000, visiting the country in 2007 to gain further insights into the reconstruction of education and in 2011 teaching at the Centre for Gender, Culture and Development. Using a gender lens, the author reflects on teaching gender research methods, the interactions with an amazing first cohort of students and the immense leadership potential shown by the students. The chapter concludes with some recommendations and implications.
\end{abstract}

\section{The Personal and Professional Context of the Author}

My interest in education in developing countries and educational reform in transitional societies is a result of working in countries where systems of education were being re-established after years of political turmoil. As head teacher of schools in Uganda and Rwanda, I have been part of education reform efforts and have often experienced the frustrations and the challenges associated with the rehabilitation and reconstruction process. My interest in development

How to cite this book chapter:

Dantas, J. 2021. Teaching Gender Research Methods for Leadership: Reflections from Rwanda. In: Randell, S., Yerbury, H. and Escrig-Pinol, A. (eds.) Gender and Learning in Rwanda. Pp. 53-63. Sydney: UTS ePRESS. DOI: https://doi. org/10.5130/aag.e. License: CC BY-NC-ND. 
education, educational reform and sustainable education has evolved over the years and forms part of the background for this chapter.

I have lived and worked in five countries-India, Kenya, Uganda, Rwanda and Australia - and undertaken research and teaching consultancies in Pakistan, Kosovo, Timor-Leste, Sri Lanka, Singapore, Tanzania and South Africa. I thus had experiences as a teacher, head teacher, teacher educator, researcher and academic. I was educated and had worked in India and was always aware of the immense problems associated with an ever-increasing population, severe regional disparities in educational access and reduced opportunities for girls and women. In a country with a billion people, India also educates some of the leading scientists, doctors and software specialists in the world, but even today has millions of children with no access to primary and secondary schooling. Indeed, the problems of child labour and gender inequalities are still widely prevalent. With respect to education, India does not produce statistics as a whole because of severe regional disparities (Bhatty, Saraf \& Gupta, 2017).

I moved to Kenya in 1990, where, in my second year as a school teacher, the country had elections which resulted in a severe economic collapse and a gradual breakdown in the social fabric of life with escalating crime, ethnic violence, the HIV/AIDS pandemic and an increase in street children (Ministry of Education and Human Resource Development, 1998). At that time, Kenya already had the support of a number of aid organisations and non-governmental organisations (NGOs)doing work in the areas of primary and secondary education, teacher training, science education and laboratory instruction (Aga Khan Education Services, AKDN, n.d.).

From 1993 to 1997, I worked as a headteacher in Uganda, rebuilding a school that had closed down in 1972 during the Idi Amin era. In the midst of gunfire at night, car hijackings and the AIDS pandemic where one in seven adults was infected with the AIDS virus, I witnessed a country dedicated to rebuilding the education system and bringing the same status to Makerere University (a well-known African Commonwealth University) that existed in the pre-Idi Amin era before 1972. I was impressed with the implementation of school improvement programs, the child-to-child program (a unique program that forges links between the child, the school and the community) and secondary science education programs and observed the return of educated Ugandan citizens who had left the country during the period of turmoil and now wanted to be part of the reconstruction process (Earnest, 2003, p. 4).

After Uganda, I spent two years in Rwanda and established a private school comprising nursery, primary and lower secondary classes. I witnessed firsthand a country recovering from the genocide of 1994, and never got used to seeing young armed soldiers on the streets, increasing numbers of war orphans and AIDS orphans, displaced children and the inherent poverty. During my time in Rwanda, the country implemented its new curriculum in September 1998 with a major thrust on science and technology, established an Institute 
of Science and Technology and an Institute of Education with the main aim of increasing the number of engineers, technologists and secondary science teachers (Ministry of Education, 1998).

In 2000, I spent several months in Rwanda, collecting data for my $\mathrm{PhD}$ thesis. During this period, I worked with a multi-lingual refugee teacher from the Democratic Republic of Congo who was also a survivor of the genocide, who acted as my interpreter. On completion of my $\mathrm{PhD}$, I published a book chapter on Science Education Reform in Rwanda (Earnest \& Treagust, 2004) and in 2006 published a 16-chapter book on Education Reform in Transitional Countries (Earnest, 2006; Earnest \& Treagust, 2006). I went back to Rwanda at the end of 2007 and met with Rwandan colleagues and friends who continued to work in the education sector to further explore the changes in the education system and impacts on leadership. This led to the publication of a book chapter on challenges to school leadership in Rwanda (Earnest, 2013).

\section{Teaching Gender Research Methods in Rwanda}

I met Professor Shirley Randell in 2009 in Perth when she spoke on her work in Rwanda at a meeting of the Western Australian Branch of the Australian Institute of International Affairs. In early 2010, I invited her to speak at Curtin University on her experiences in Rwanda. Shirley reached out to me in October 2010, asking if I could come and help teach a class on Research Methods for the inaugural program in Gender, Culture and Development. I was honoured with the invitation, as it allowed me to draw on my experiences working with coursework master's students at Curtin University (in Perth, Western Australia) and my growing expertise in refugee and migrant education and health with a focus on women and youth. I was also skilled in participatory and community research using qualitative methods.

In consultation with Shirley, I developed a 10-week research methods unit with a focus on gender and feminist research methods. In order to support student learning each student was provided with a compact disk (CD) of course readings, comprising a selection of over 40 journal articles and book chapters on gender research. Presentations were delivered that provided the theory on the methods and methodologies of gender research methods and drew on feminist epistemologies. The next section provides a brief overview of feminist research that underpinned my teaching.

\section{Feminist Research}

Feminist research gives voice to marginalised and vulnerable populations and provides a platform for women to share their wisdom, experiences and opinions on issues that impact them personally. Gender equality, precipitated 
through the restructuring of traditional social hierarchies, is not only necessary for justice and human rights but is also vital for the establishment and sustainability of best practice research processes (The Lancet, 2019). Doucet and Mauthner (2007, p.42) argue that over the past three decades feminist scholars have made significant contributions to global discourse on 'issues of power, knowing, representation, reflexivity, and legitimation in methodological and epistemological discussions'. During this time, the international research community has seen the emergence and convergence of feminist epistemologies and methodologies resulting in the establishment of a new field of scholarship known as 'feminist research'. Feminist research refers to qualitative, quantitative and mixed method research that is instigated by, and directed towards, the desire to challenge social inequalities especially impacting women and girls (Doucet \& Mauthner, 2007).

To ensure inclusivity and equitability, the need to diverge from traditional research practices has seen the field of feminist research introduce methodological approaches that challenge conventional data collection, analysis and dissemination (Doucet \& Mauthner, 2007). Historically, quantitative, positivist research methods have dominated global development research. However, more recently, qualitative research methodologies have progressively gained acknowledgment as valuable tools for obtaining contextually rich data that is both female centric and culturally specific (Mack et al., 2005).

Supporting the feminist research ideology are the methodological approaches of participatory research and action research (Doucet \& Mauthner, 2007). These processes strive for the inclusivity of participants and communities within a collaborative research context and have the potential to facilitate holistic, empowering and transformative outcomes (Coghlan \& Brydon-Miller, 2014). My experience has shown that action and participatory methodologies, underpinned by a feminist research framework, enable research to not only be about women, but also to be conducted for women and with women (Doucet \& Mauthner, 2007; Coghlan \& Brydon-Miller, 2014) because it relates to the context of their every-day lives.

In this first semester of study for the students enrolled in the master's program, students were introduced to a range of research methods associated with feminist research: ethnography, life history, participatory research, action research, case studies and linked them to examples from published research undertaken by my students and myself. Through these research methods and the associated readings, students learned about empowerment, resilience, inequalities and complex human and socio-cultural issues in practice, concepts introduced to them in other theoretically based subjects.

The journal articles provided a glimpse of arranged marriages in South Asia, gender-based violence in Papua New Guinea, homosexuality and issues of gender differences. As part of the course assignment, students were assigned to groups and had to undertake a group PowerPoint presentation on a journal 
article of their choice. This analysis and critique of the work of established scholars was new to the students but they readily accepted the task. From this exercise, students began to understand the strengths and weaknesses of particular research methods and the ways they were implemented. This background and learning helped them develop their own knowledge base and gave them insights into feminist research which they could integrate into the research proposal they prepared, which would later form the basis of their master's projects.

It was a privilege to teach this passionate group. It was wonderful to see a cohort of mixed age students that included nine male students. Most of the students were mature age and nearly all were working full time, but all were keen to learn and felt privileged to be given the opportunity to be part of this exciting new master's course. Most students shared about their personal and professional lives, some had important government jobs, others worked in NGOs and some with international organisations. An exciting outcome from this learning experience was that in 2015, two of the students, now graduates, presented at the Commission on the Status of Women (CSW59) at the UN in New York, alongside Shirley Randell and me. One of the graduates went on to become the Minister of Gender in Rwanda in 2015 and I was privileged to meet her at CSW60 in New York and attend a session hosted by the Rwandan delegation to the CSW60 on Rebuilding in Rwanda and gender development.

\section{My Reflections}

Reflecting on my experiences of teaching the first cohort, I found that the students valued the mentoring and teaching provided in the classes. They proved to be resilient and empowered and their families played an important role in their development. Many of the students, both men and women, displayed leadership qualities and were passionate about making a difference in Rwanda and the world. The concepts of resilience, empowerment, leadership and mentoring with a focus on the student cohort have been examined in the next section. As noted earlier, these concepts underpin much of the scholarship developed through feminist research methods and were fundamental to the scholarly, professional and personal development of the students.

\section{Resilience}

The definition of resilience provided by Atkinson, Martin and Rankin (2009, p. 137 ) is 'the ability to recover readily from the extremes of trauma, deprivation, threat or stress'. Similarly, Rutter (2007, p. 208) states that resilience is observed when individuals have 'relatively good outcomes despite exposure to adverse life experiences'. According to Walsh (1996, p. 7) 'resilience is forged through 
adversity, not despite it'. Resilience is also considered a dynamic process that varies and evolves over time (Luthar, Cicchetti \& Becker, 2000; Mullin \& Arce, 2008). What binds these definitions together is that they suggest there is an element of recovery of the individual from difficult events (Bonanno et al., 2007) and include protective factors that may promote resilience at the individual level, such as good social support, family and good health. The students in the master's in gender classes were extremely resilient; most had lived as refugees, had experienced the genocide and were involved in rebuilding their country. They were all zealous about the desire to further their qualification so they could make a difference and become leaders. Studying in the program was not without its difficulties, with some students travelling long distances to attend classes, others having to balance domestic and work responsibilities, and others still coming to terms with studying in English, their third or fourth language.

\section{Empowerment}

Empowerment is inextricably related to and relevant for particular cultural and social contexts in which people live (Mohajer \& Earnest, 2009). Freire (1999) describes empowerment as a cultural synthesis, where all involved in the empowerment process undergo change, and knowledge is shared equally. This knowledge has the power to enact social action and bring about change. Empowerment has been successfully incorporated into a variety of disciplines (social work, development, education and human rights) including participatory or action research. An all-encompassing definition of empowerment by UNESCO is: 'How individuals/communities engage in learning processes in which they create, share knowledge, tools and techniques in order to change and improve the quality of their own lives and societies' (Faccini and Jain, 2000.). The students in the first cohort were engaged in the new learning they were receiving, and empowered by it to further create new knowledge for leadership and change in Rwanda. They learned the value of evidence-based practice. Some were empowered very soon after the completion of the course to take their own new knowledge into broader scholarly and policy arenas, so that they or others could work towards implementing these new understandings, supporting changes to the quality of life for many Rwandans.

\section{Family}

The family has been known to serve as a protective or risk factor in an individual's life (Caplan, 1982; Wolin \& Wolin, 1993). A separate body of research considers the family as an important unit of support (McCubbin et al., 1997; Patterson, 2002; Walsh, 1996). Family resilience has been described as how families use their strengths as a buffer in times of stress (Hawley \& DeHaan, 
1996). Strong connectedness and being able to seek reassurance and safety are all factors that can help increase family resilience. These strong connections, and the need for social and cultural cohesiveness are observed within the family (Brookes, 2010). Family played a vital role in the lives of all students. Nearly all were parents, with a couple of pregnant young women in the class, and most had significant support from their families. They shared information about their families, formally and informally, were proud of their children and wanted to be strong role models. They were also trying to find ways to live by the principles they were learning about, and sometimes portraying themselves through action research or auto-ethnographic projects.

\section{Mentoring}

Mentoring has been defined as a one-to-one relationship in which an experienced older career person guides and supports the career development of a new or early-career member. Sorcinelli and Yun (2007) have proposed a model that encourages a broader, more flexible network of support, in which no single person is expected to possess the expertise required to help someone navigate a career. In this model, robust networks are established by engaging multiple 'mentoring partners' in non-hierarchical, collaborative, cross-cultural partnerships to address specific areas of mentoring, such as research, teaching, working towards success and striking a balance between work and life. These reciprocal partnerships benefit the 'protégé' and also the 'mentor'. The tutors and visiting professors from around the world provided mentoring to the students, advising, sharing and providing valuable guidance from their own personal experiences. The students themselves, as noted above, were already highly experienced professional women and men, and their sharing of experiences and open discussions, especially in the clarification of the research questions for the thesis, enabled a mentoring among peers, as they workshopped their ideas and received comments and feedback from those with different perspectives and experiences.

\section{Implications and Conclusion}

In spite of the immense difficulties and constraints in education in Rwanda, the master's students provide a portrayal of human experience in this transitional society. In a recent article in The Conversation, Karangwa and Bayisenge (Feb 2018) point to a significant disconnect between Rwanda's international reputation for gender equality and the lived realities on the ground. While the focus of their article was on girls with disabilities, their call for unified policy approaches highlights the need for strong and proactive national strategies that involve multiple sectors (health, education, labour and youth). 
The women from the first cohort of the degree in Gender, Culture and Development in Rwanda were passionate community advocates and played a supportive role in their communities. They displayed a strong social justice and human rights conscience. They presented great resilience and were involved in the rebuilding of their country. They took on the challenge of accepting senior government and NGO leadership positions often learning new skills on the way. The contribution of the men should not be overlooked. Their example in this research methods class was a constant reminder that a feminist research methodology is not the province only of women. Men, too, can strive for new scholarly knowledge and social change, leading to gender equality, using collaborative and inclusive research methods. My experience of teaching in Rwanda resonates with the vital and uncontested importance of education, the desire to be empowered, the capacity to be resilient and adaptive, and the importance of giving back to the community.

A key recommendation arising from this experience is to continue to provide women with avenues to feel empowered, to have opportunities to further their education, to offer adaptive structures and mechanisms that build resilience, and to grow strong communities where both men and women are engaged in a constant dialogue for growth. It is my hope that through transnational alliances and collaboration, we can bring about capacity building and transitional impacts and harness the immense leadership that women in Rwanda have.

The implications from this chapter provide a foundation for sustainable, relevant education and gender development in complex transitional societies. To successfully take advantage of emerging realities in Rwanda will depend on the quality of its educational and human resources. This is key to meeting Rwanda's pledge of removing all obstacles against women's development. The degree of success in this regard will depend on the abilities of Rwandans to critically understand, adapt and reshape their country through education that benefits all Rwandans.

\section{References}

Aga Khan Education Services, AKDN (n.d.), The Aga Khan Foundation's Education Activities, Available at: http://www.akdn.org/agency/akes.html [Accessed 03/31/20].

Atkinson, P, Martin, C and Rankin, J 2009, 'Resilience revisited', Journal of Psychiatric and Mental Health Nursing, vol. 16, no. 2, pp. 137-145, Available at: https://doi.org/10.1111/j.1365-2850.2008.01341.x [Accessed 03/31/20]. Bhatty, K, Saraf, R and Gupta, V 2017, Out of school children in India: some insights on what we know and what we don't, Working Paper, Center for Policy Research India, New Delhi. Available at: http://cprindia.org/ 
research/papers/out-school-children-india-some-insights-what-weknow-and-what-we-dont [Accessed 03/31/20].

Bonanno, G, Galea, S, Bucciarelli, A and Vlahov, D 2007, 'What predicts psychological resilience after disaster? The role of demographics, resources, and life stress', Journal of Consulting and Clinical Psychology, vol. 75, no. 5, pp. 671-682. Available at: https://doi.org/10.1037/0022-006X.75.5.671 [Accessed 03/31/20].

Brookes, G 2010, 'The multilayered effects and support received by victims of the Bali bombings: A cross cultural study in Indonesia and Australia, $\mathrm{PhD}$ thesis, Curtin University.

Caplan, G 1982, 'The family as a support system', in McCubbin, H, Cauble, A and Patterson, J (eds) Family stress, coping, and social support, Charles C. Thomas, Springfield, IL, pp. 200-220.

Coghlan, D and Brydon-Miller, M 2014. The Sage Encyclopedia of Action Research, SAGE, London.

Doucet, A and Mauthner, N 2007, 'Feminist methodologies and epistemology', in Bryant, C and Peck, D (eds) 21st Century Sociology, SAGE, Thousand Oaks, CA, pp. 36-42.

Earnest, J 2003, 'Science education reform in a post-colonial developing country in the aftermath of a crisis: the case of Rwanda', $\mathrm{PhD}$ thesis, Curtin University.

Earnest, J 2006, 'Science education reform in a transitional society: the case of Rwanda', in Earnest, J and Treagust, D (eds) Education Rebuilding in Societies in Transition: International Perspectives, Sense, Rotterdam, pp. $129-145$.

Earnest, J 2013, 'Challenges to school leadership in post-genocide Rwanda', in Clarke, S and O'Donoghue, T (eds) School-level Leadership in Post-Conflict Societies: The Importance of Context, Routledge, London, pp. 78-94.

Earnest, J and Treagust, D 2004, 'Science education reform in Rwanda: a window to understanding change through dilemmas', in Mutua, $\mathrm{K}$ and Sunal, C (eds) Research in Education in Africa, the Caribbean, and the Middle East, Information Age, Charlotte, NC, pp. 59-80.

Earnest, J and Treagust, D 2006, Education Rebuilding in Societies in Transition: International Perspectives, Sense Publishers, Rotterdam, Netherlands.

Faccini, B and Jain, M 2000, Technology and learning: definitions, UNESCO, Available at: https:/unesdoc.unesco.org/ark:/48223/pf0000135410?pos InSet=1\&queryId=3f2fa233-444b-4e87-a5c4-0277499c4be4 [Accessed 03/31/20].

Freire, P 1999, Pedagogy of the Oppressed, Rev. ed., Continuum, New York.

Hawley, D and DeHaan, L 1996, 'Toward a definition of family resilience: Integrating life-span and family perspectives', Family Process, vol. 35, no. 3, pp. 283-298. 
Karangwa, E and Bayisenge, J 2018, 'How Rwandan girls with disabilities are fighting sexism at school, The Conversation, 22 April 2018. Available at: https://theconversation.com/how-rwandan-girls-with-disabilities-arefighting-sexism-at-school-94456 [Accessed 03/31/20].

Kenya, Ministry of Education and Human Resource Development 1998, National Primary Education Baseline Report. The State of Primary Education in Kenya. Nairobi, Kenya: Ministry of Education.

The Lancet 2019, 'Feminism is for everybody', The Lancet, vol. 393 no.10171, p. 493. Available at: https://doi.org/10.1016/S0140-6736(19)30239-9 [Accessed 03/31/20].

Luthar, S, Cicchetti, D and Becker, B 2000, 'The construct of resilience: a critical evaluation and guidelines for future work', Child Development, vol. 71, no. 3, pp. 543-562. Available at: https://doi.org/10.1111/1467-8624.00164 [Accessed 03/31/20].

Mack N, Woodsong C, MacQueen KM, Guest G, Namey E 2005, Qualitative research methods: a data collector's field guide, Family Health International, North Carolina.

McCubbin, H, McCubbin, M, Thompson, A, Sae-Young, H and Allen, C 1997, 'Families under stress: What makes them resilient', Journal of Family and Consumer Sciences, vol. 89, no. 3, pp. 2-11.

Mohajer, N and Earnest, J 2009, 'Youth empowerment for the most vulnerable: A model based on the pedagogy of Freire and experiences in the field', Health Education, vol. 109, no.5, pp. 424-438, Available at: https://doi. org/10.1108/09654280910984834 [Accessed 03/31/20].

Mullin, W and Arce, M 2008, 'Resilience of families living in poverty', Journal of Family Social Work, vol. 11, no.4, pp. 424-440, Available at: https://doi. org/10.1080/10522150802424565 [Accessed 03/31/20].

Patterson, J 2002, 'Understanding family resilience', Journal of Clinical Psychology, vol. 58, no.3, pp. 233-246, Available at: https://doi.org/10.1002/ jclp.10019 [Accessed 03/31/20].

Rutter, M 2007, 'Resilience, competence, and coping', Child Abuse \& Neglect, vol. 31, no.3, pp. 205-209, Available at: https://doi.org/10.1016/j. chiabu.2007.02.001 [Accessed 03/31/20].

Rwanda, Ministry of Education 1998, Plan of action for education in Rwanda (1998-2000): Recovery and development. Ministry of Education with support of UNDP and UNESCO, Ministry of Education, Kigali, Rwanda.

Sorcinelli, M and Yun, J 2007, 'From mentor to mentoring networks: Mentoring in the new academy', Change: The Magazine of Higher Learning, vol. 39, no. 6, pp. 58-61, Available at: https://doi.org/10.3200/CHNG.39.6.58-C4 [Accessed 03/31/20].

University of Rwanda, Available at: https://theconversation.com/institutions/ university-of-rwanda-1960, [Accessed 03/31/20]. 
Walsh, F 1996, 'The concept of family resilience: crisis and challenge', Family Process, vol. 35, no.3, pp. 261-281. Available at: https://doi.org/10.1111/ j.1545-5300.1996.00261.x [Accessed 03/31/20].

Wolin, SJ and Wolin, S 1993, The Resilient Self: How Survivors of Troubled Families Rise Above Adversity, Villard Books, New York.

\section{Contributor Biography}

Dr Jaya Dantas is Professor of International Health and Dean International in the Faculty of Health Sciences at Curtin University in Western Australia. Her research and teaching focusses on refugee and migrant health, the social determinants, health equity and gender. Professor Dantas has worked for 30 years in India, Kenya, Uganda, Rwanda, Australia, Timor Leste, Sri Lanka and Singapore. She is a passionate advocate for education of women and youth. As a migrant woman and global health educator and researcher, she has expertise in gender, health and education. 